\title{
Indonesia's mud disaster probably had natural causes
}

\author{
Earthquake, not drilling, is likely to have caused 2006 eruption in Java.
}

Quirin Schiermeier

22 July 2013

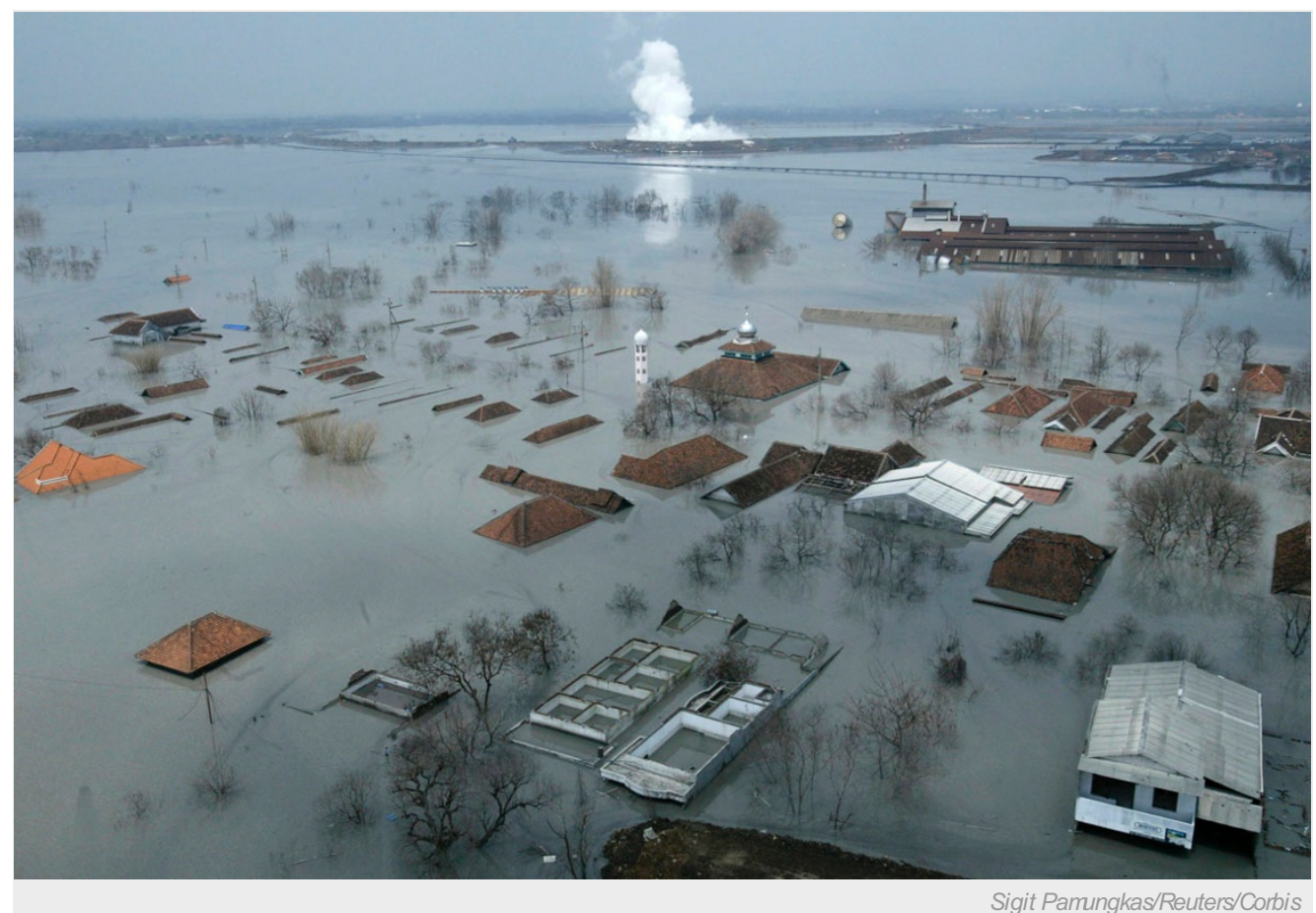

A 'mud volcano' eruption that began in 2006 flooded houses in Sidoarjo, in Indonesia's East Java province, seen here in April 2007. A new study finds that an earthquake 250 kilometres away caused the eruption, exonerating nearby gas exploration wells.

The mud flow that wiped out a Javanese town in 2006 was probably not triggered by commercial drilling, which had previously been blamed. A new study ${ }^{1}$ provides evidence that seismic waves from a preceding earthquake, focused by an unusual geologic formation, mobilized the deadly mud from its underground source.

On 29 May of that year mud began to spill from the ground in the middle of a rice paddy near Sidoarjo in East Java, Indonesia. What first seemed a bizarre whim of nature would soon turn into a nightmarish catastrophe as the mud relentlessly continued to pour out and all efforts to plug the hole were in vain. In the end, some 40,000 residents lost their homes.

The Lusi eruption — short for 'lumpur Sidoarjo', lumpur being the Indonesian word for mud — has continued ever since, albeit at lessening pace. At present, a mud geyser erupts every 30 seconds or so in the middle of a 100 metre-wide crater at the desolate site.

The mud probably originates from more than a kilometre down, from a layer of rigid clay that deposited over geological time scales and then somehow became liquid and found cracks through which it could flow to the surface. But what triggered the disaster has been a matter of heated debate.

Some suggested that it could have been drilling conducted by the Indonesian company Lapindo Brantas at a gas exploration well nearby ${ }^{2}$. Among locals, it has become commonplace to blame the company for what happened.

Lapindo Brantas published its own research on the matter ${ }^{3}$ and rejects responsibility for the catastrophe. Nonetheless, since 2006 the company has contributed some US\$570 million in disaster aid to affected residents and communities.

"It is very difficult to believe that drilling could have caused this enormous erupion," says Adriano Mazzini, a geologist at the University of Oslo in Norway who has done extensive in situ studies in Java. 
Many researchers thought the cause was more likely to be a shallow magnitude 6.3 earthquake that struck 250 kilometres away 47 hours before the onset of the mud eruption. But some geologists held that the seismic waves radiating from the epicentre of that quake would not have been powerful enough to trigger a deep tectonic response at such great distance.

Now a study in Nature Geoscience ${ }^{1}$ lends support to the case of a natural, rather than a man-made, disaster. Using seismic data to image the geology of the disaster site, the authors identified a layer of hard and dense rock, shaped like a giant satellite dish, sitting on top of the mud reservoir. A computer model showed that because of its peculiar geometry and the composition of the rock, the feature could have acted as a reflector for seismic waves, triggering the eruption.

"It was a chain reaction," says Stephen Miller, a geophysicist at the University of Bonn who led the research. "Seismic energy from the quake, reflected and focused by the surrounding rocks, became sufficiently concentrated to liquefy the mud source."

According to the study, the mud fluid then injected itself into the adjacent Watukosek Fault and caused it to slip, thus linking it to the hydrothermal volcanic system deeper down. "As a result," says Miller, " that previously trapped system completely rearranged itself and, fatally, got connected to the free surface. Then the mud came."

Subsurface structures that amplify seismic energy have been previously identified only in ordinary, magmatic volcanoes. The presence of the parabolic reflector may well explain the scale and longevity of the Lusi eruption, says Achim Kopf, a geologist at the University of Bremen in Germany.

Seismic profiles by Mazzini and collaborators ${ }^{4}$ suggest that pressure had been growing up for about 30 years and that by 2006 the system was ready to erupt. "It was meant to happen," he says. "The quake was just the final trigger."

The long-running controversy over the cause of the eruption has stood in the way of more effective humanitarian aid to the affected people, says Jeffrey Richards, the executive director of the Humanitus Sidoarjo Fund in Melbourne, Australia, a charity that works with the Indonesian government on scientific and social issues in the disaster region. "It's definitely time to move away from that fruitless controversy and help the people of Indonesia to cope with an epic disaster they cannot handle alone."

Nature | doi:10.1038/nature.2013.13421

\section{References}

1. Lupi, M., Saenger, E. H., Fuchs, F. and Miller, S. A. Nature Geoscience http://dx.doi.org/10.1038/ngeo1884 (2013).

2. Davies, R. J.et al., Earth Planet. Sci. Lett. 272, 627-638 (2008)

3. Sawolo, N. et al., Mar. Petrol. Geol. 26, 1766-1784 (2009).

4. Mazzini, A. et al. Mar. Petrol. Geol. 26, 1751-1765 (2009). 